\title{
A Systematic Literature Review on Disruptive Technologies in Higher Education
}

\author{
Effulgence \\ Vol. 20, No. 1 \\ January - June 2022 \\ Rukmini Devi Institute of Advanced Studies \\ E-mail : effulgence@rdias.ac.in, Website : www.rdias.ac.in \\ http://effulgence.rdias.ac.in/user/default.aspx \\ https://dx.doi.org/10.33601/effulgence.rdias/v20/i1/2022/12-26
}

\begin{abstract}
Ms. Nidhi $\operatorname{Singh}^{1} \square$
Ms. Disha Garg
\end{abstract}

\begin{abstract}
In today's world, technology has tangible impact on existing market and to sustain for leading firms and industries become big challenge. Education is indispensable part of this modern society and it is also undergoing to drastic change due to changes in industries. The changes in the industry have put a big challenge in educational sector where reforms are required to go with the trends in the current scenario. I will like to say in a few words that disruptive is not a disruptive but a way of delivering outcome in a different way. The systematic literature review of past 20 years collates and compares studies on these disruptive technologies in higher education published between 2010 and 2021. This study helps as a tool to researcher, academician, policymakers, and practitioners associated with education systems to get broader view to identify characteristic of disruptive technology in the higher education and also to understand the impact of disruptive technology on the higher education. In addition, this study helps further to academician in their decision making how to incorporate these technologies in classroom. The evidence from this review suggests that need of Industries 4.0 and what changes are required in existing current education pedagogy. Further it helps to introduce new concept of Life-Long Learning process.
\end{abstract}

Keywords: Disruptive Technology, systematic literature review, Education 4.0, Industry 4.0.

\section{INTRODUCTION}

$\mathrm{T}$ he fourth industrial revolution has begun and is marked by the increased connectedness and participation, as well as advances in the digital technology, virtual reality \& artificial intelligence and communication technology will likely have an impact on various enterprises, taken into consideration the increasing convergent borders between the humans, robots, \& other resources. "One of them has something to do with education."

To address the Industrial Revolution, a country's quality of educators and academicians, are directly linked to industrial revolution 4IR. Academician

1. Assistant Professor, Rukmini Devi Institute of Advanced Studies, Rohini, nidhi.singh@rdias.ac.in

2. Assistant Professor, Rukmini Devi Institute of Advanced Studies, Rohini, disha.garg@rdias.ac.in 
need to be competent as well as adaptable to rapidly changes technology and global challenges as well. Each professional higher educational institute must develop new assumed academic policy and academic literacy in the current scenario. In an interactive learning environment, traditional instruction is neither the primary nor an adequate method of learning. Educators can profit from active learning methods that engage pupils. One technique to supplement traditional training is to increase experiential activities through the use of technology. In today's digital environment, data literacy refers to the capacity to comprehend, interpret, and apply data. While technology literacy corresponds to the capacity to know the workplace mechanics \& technology, the human resource literacy is relates to the ability to engage efficiently, not rigidly, but with character (Siu, K. W. M., \& Garca, G. J. C. 2017).

Education is essential for the growth of a generation that is creative, innovative, and competitive. It can be achieved by using technology as an instructional tool that can adapt to and improve the period. To fulfill the needs of digital technology, Indonesia, like the rest of the globe, must increase the quality of its graduates."

The move to Education 4.0 has resulted in improved flexibility, the evolution of educational delivery, and increased personalization, all of which are necessary to satisfy the needs of today's students. The epidemic has accelerated the use of online education, and a global trend toward digital and technology-enabled learning has served as a test bed for Education 4.0 and its emphasis on digital learning. According to Fisk (2017), "the new vision of learning pushes learners to acquire not only the necessary skills and knowledge but also to identify the sources from which they might obtain these skills and knowledge."

As per Fisk and Aziz Hussin (2017), nine themes are associated to the Education 4.0, the first and most essential of which is that students can learn at any time, from any location, and at their own discretion.
The second trends, learning will be personalized for each learner. Students have the option of studying in a way that suits them in the third trend. The fourth tendency is that children would be exposed to the project-based learning. Fifth trends, practical exposures like internships, mentoring programs, and collaborative projects give students additional chances for hands-on learning. Students were exposed to data analysis and interpretation from an early age, and they were required to apply their theoretical knowledge to data as well as use their critical and reasoning skills to evaluate the current data presented sets logically. The seventh trend, student's assessment and evaluations methods changes, like digital pop quizzes, online polls, live case study, role plays, group assignment and tasks, and break out room projects are examples of new assessment techniques. Eighth, by maintaing constant feedback loop system from students' enhance the curriculum and pedagogy. Finally, due to continuous changes in technology and new evolving disruptive technologies were coming, it's shifted the role of teacher from teachers to facilitators to mentors. The primary commitment of instructors to pupils has been altered by nine changes introduced by the Education 4.0 movement. Rather than viewing the transformation as a threat to current teaching techniques, educators must play a role in facilitating it. Individuals and communities who embrace this educational trend will acquire a broad range of competencies, abilities, and information that will enable them to express their creative potential completely.

\section{METHODOLOGY}

\section{Systematic Literature Review}

The present study examines the literature in qualitative, quantitative, and mixed-methods research in depth. The review of literature uses scientific data from primary studies on latent tuberculosis in immigrant groups to find, analyse, and synthesise scientific information. 
A systematic literature review, according to Boland et al. (2013), is basically designed to "find, appraise, and synthesise" the best available evidence relevant to the specific research issue in order to propose educated evidence-based solutions. A comprehensive examination of the literature aids faculty, policymakers, and academia in assessing if the evidence pertains to teaching and learning in evidence-based disruptive technologies.

It offers which disruptive technology would be best for academia as well as how its impact the teaching and learning style (Bettany-Saltikov, 2012). The approach taken in this study is relevant to the study of different types of disruptive technologies, as it provides insight into its characteristics, barrier, advantage and attitudes in adopting different types of disruptive technologies among academician.

\section{Search Strategy}

The following databases were searched for the current study: Web of Science, ERIC, Scopus, IEEE
Xplore Emerald, and Springer. These databases are much popular due to the large number of articles which they contain \& the ease with which they provide access to pertinent research topics.

In these databases, search topics included the terms "gamification," "webcasting," "simulation," "augmented reality," "virtual reality," "AR/VR," "higher education," "education," "education technology/ies," "management," "faculty," "teacher," "academician," and "academic." The term "higher education" is used broadly in this study to encompass management, engineering, social science, and professional higher education.

To guarantee that time is spent filtering down acceptable literature, search criteria must be refined (Holly, Salmond, \& Saimbert, 2011). The second stage of manual search was undertaken on bibliographies of the selected papers to guarantee that most relevant publications were found. To reduce the risk of missing relevant sources, a final internet search was conducted using Google Scholar.

Table 1

\begin{tabular}{|c|c|c|}
\hline Database & Search Items & Results \\
\hline Web of Science & $\begin{array}{l}\text { Article; Data Range from } 2011 \text { to } 20121 . \text { \#1 disruptive } \\
\text { technologies" OR disruptive technology \#2 "gamification," \#3 } \\
\text { "webcasting," \#4 "simulation," \#5 "augmented reality", \#6 } \\
\text { "virtual reality", \#7 "AR/VR", \#8 "disruptive technology/ies", } \\
\text { \#9 "higher education", \#10 "education", \# } 11 \text { "education } \\
\text { technology/ies", \#12 "management", \#13 "faculty", \#14 } \\
\text { "teacher", "academician" \#16 "academic" }\end{array}$ & 563 \\
\hline ERIC & $\begin{array}{l}\text { Article; Data Range from } 2011 \text { to } 20121 . \text { \#1 disruptive } \\
\text { technologies" OR disruptive technology \#2 “gamification," \#3 } \\
\text { "webcasting," \#4 "simulation," \#5 "augmented reality", \#6 } \\
\text { "virtual reality", \#7 "AR/VR", \#8 “disruptive technology/ies", } \\
\text { \#9 "higher education", \#10 "education", \# } 11 \text { "education } \\
\text { technology/ies", \#12 "management", \#13 "faculty", \#14 } \\
\text { "teacher", "academician" \#16 “academic" }\end{array}$ & 428 \\
\hline Scopus & $\begin{array}{l}\text { Article; Data Range from } 2011 \text { to } 20121 . \text { \#1 disruptive } \\
\text { technologies" OR disruptive technology \#2 “gamification," \#3 } \\
\text { "webcasting," \#4 "simulation," \#5 "augmented reality", \#6 } \\
\text { "virtual reality", \#7 "AR/VR", \#8 "disruptive technology/ies", } \\
\text { \#9 "higher education", \#10 "education", \# } 11 \text { "education } \\
\text { technology/ies", \#12 "management", \#13 "faculty", \#14 } \\
\text { "teacher", "academician" \#16 "academic" }\end{array}$ & 708 \\
\hline
\end{tabular}




\begin{tabular}{|c|c|c|}
\hline IEEE Xplore & $\begin{array}{l}\text { Data Range from } 2011 \text { to } 20121 \text {. \#1 disruptive technologies" } \\
\text { OR disruptive technology \#2 "gamification," \#3 "webcasting," } \\
\text { \#4 "simulation," \#5 "augmented reality", \#6 "virtual reality", } \\
\text { \#7 "AR/VR", \#8 "disruptive technology/ies", \#9 "higher } \\
\text { education", \#10 "education", \# } 11 \text { "education technology/ies", } \\
\text { \#12 "management", \#13 "faculty", \#14 "teacher", } \\
\text { "academician" \#16 "academic" }\end{array}$ & 510 \\
\hline Emerald & $\begin{array}{l}\text { Data Range from } 2011 \text { to } 20121 \text {. \#1 disruptive technologies" } \\
\text { OR disruptive technology \#2 "gamification," \#3 "webcasting," } \\
\text { \#4 "simulation," \#5 "augmented reality", \#6 "virtual reality", } \\
\text { \#7 "AR/VR", \#8 "disruptive technology/ies", \#9 "higher } \\
\text { education", \#10 "education", \# } 11 \text { "education technology/ies", } \\
\text { \#12 "management", \#13 "faculty", \#14 "teacher", } \\
\text { "academician" \#16 "academic" }\end{array}$ & 569 \\
\hline Springer & $\begin{array}{l}\text { Data Range from } 2011 \text { to } 20121 \text {. \#1 disruptive technologies" } \\
\text { OR disruptive technology \#2 "gamification," \#3 "webcasting," } \\
\text { \#4 "simulation," \#5 "augmented reality", \#6 "virtual reality", } \\
\text { \#7 "AR/VR", \#8 "disruptive technology/ies", \#9 "higher } \\
\text { education", \#10 "education", \# } 11 \text { "education technology/ies", } \\
\text { \#12 "management", \#13 "faculty", \#14 "teacher", } \\
\text { "academician" \#16"academic" }\end{array}$ & 445 \\
\hline
\end{tabular}

\section{Inclusion \& Exclusion Criteria}

The systematic literature review included both qualitative and quantitative research. Only papers that had been published in English were included in the search. It was also vital for the publication to be current, which necessitated limiting the publication period to 2011-2021.

However, the study was limited in scope in that it only focused at disruptive technologies in higher education. There were no reviews of literature included in this research.

This literature review also eliminated studies that included any type of randomised control trial. These studies were removed due to a lack of the relevant data on the themes that were used to analyse the literature in their findings and conclusions.

\section{Study Selection}

The initial results, based on the above-mentioned data, yielded a total of 3,223 articles. The duplicates and overlapping articles were removed from every database; the total number of articles was decreased to 2,393. (828 duplicates). Following that, titles \& abstracts were examined, resulting in the removal of 2,040 publications that were unrelated to the research topic.

The remaining 348 publications were then read in full, both abstracts and full-text versions, resulting in 61 articles being chosen as matching the inclusion criteria. The bibliographies of each paper were then searched, as well as searches on Google Scholar, which yielded a total of 9 articles that matched the inclusion requirements. The literature review included a total of 70 papers that were finalised.

A total of 70 papers were finalised for the literature review. The articles were then collected into a matrix in order to synthesise them based on the topics that had been devised for examination. Screening disruptive technologies in higher education is one of the topics covered. The matrix of studies can be found in appendix A. 


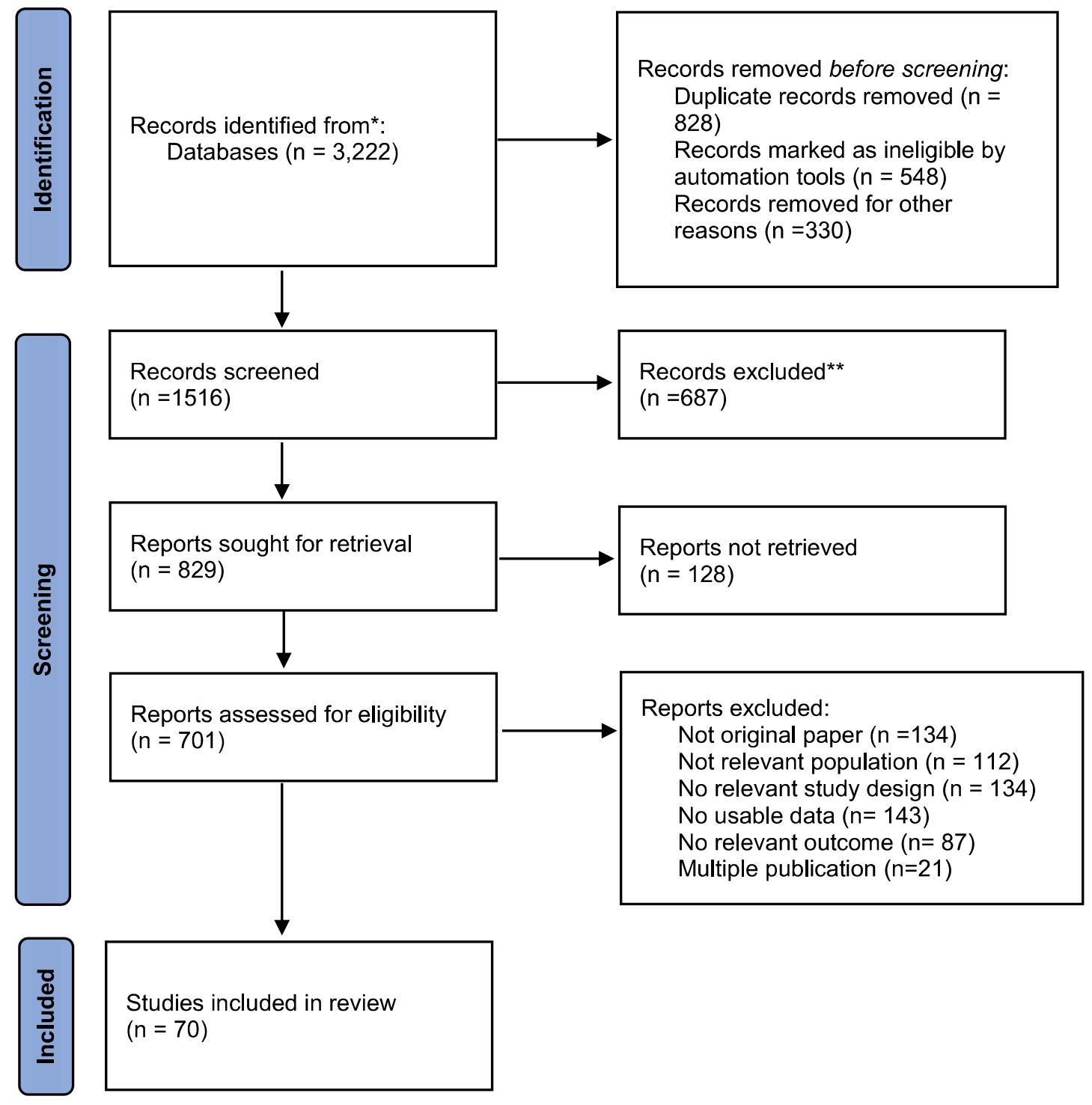

Figure 1

Source: The PRISMA 2020, Page MJ, McKenzie JE, Bossuyt PM, Boutron I, Hoffmann TC, Mulrow CD, et al.

\section{Framework for Analysing Research Articles}

Baker (2014) stated that when evaluating a piece of literature, it is important to become familiar with the work in order to assess its relevance, strengths, and limits in relation to the research question. As a result, the approach presented by Caldwell et al. (2005) for criticising literature has been adopted as the norm for the review of literature (see fig.2). 


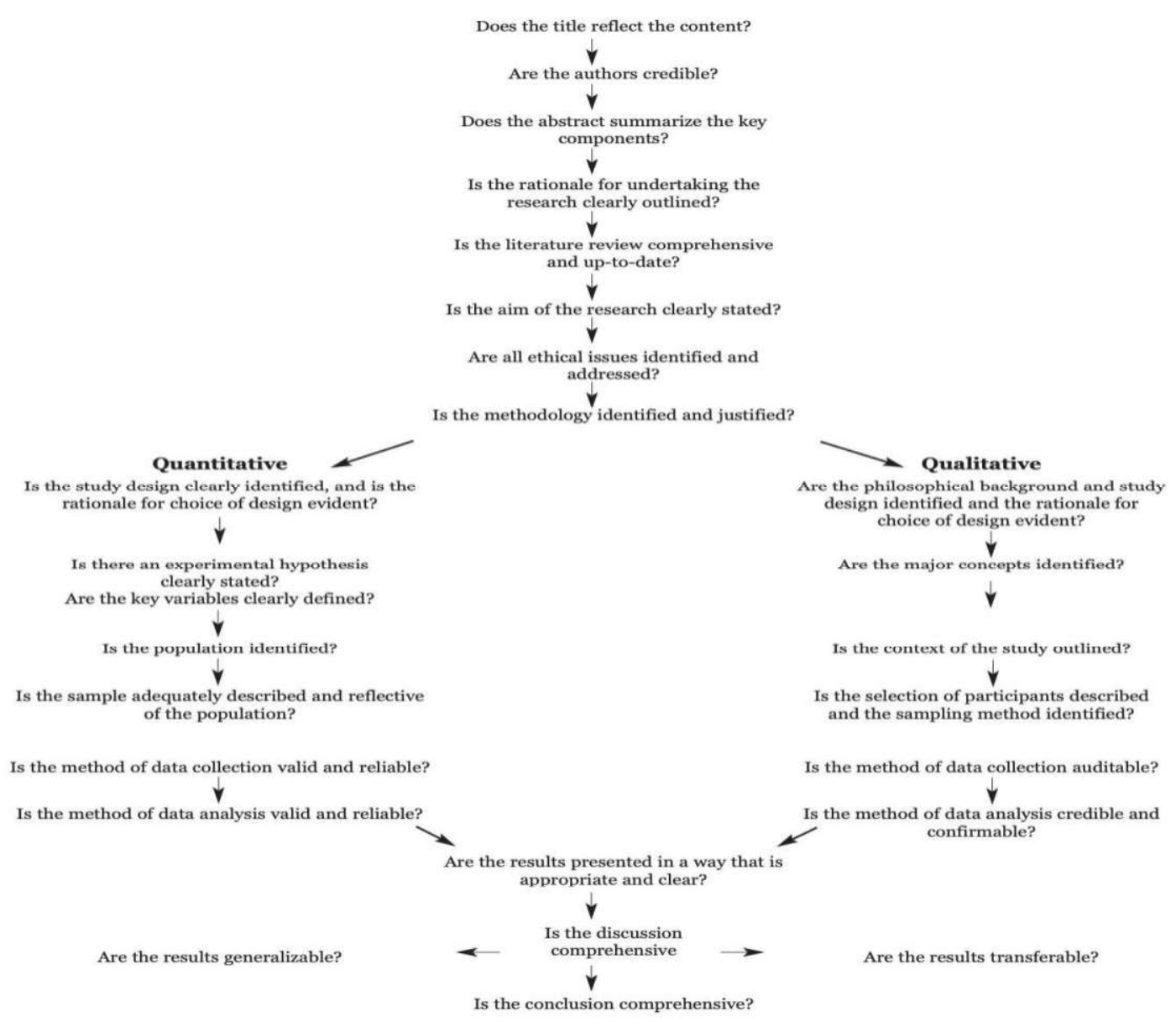

Figure 2 - Research Critique Framework (Caldwell et al., 2005)

Caldwell et al. (2005) proposed a model that incorporates a fundamental framework that divides the critiquing process into four key issues that must be addressed in order to be successful.

Making certain that the literature review is current and thorough; ensuring that the sample is adequately described and representative of the population in quantitative studies; ensuring that the selection criteria for recruiting patients are described and a sampling method is identified in qualitative studies; and ensuring that the study's conclusion is thorough are all important considerations (Caldwell et al., 2005).

\section{Disruptive Technologies versus Disruptive Innovations}

Both terms are used interchangeably in the business and education literature and this often leads to ambiguity and confusion. According to Christensen (1997), disruptive technologies are typically innovations in technology, whereas disruptive innovations change radically entire markets and this is the major difference: the consequences of the latter and the threats they (might) pose have a bigger impact and are felt more deeply and by more people. A technology is considered disruptive when it affects an existing business model and/or the core values in the organisation where the technology is to be implemented. The author of this thesis argues that disruptive technologies or innovations do not appear suddenly or in a vacuum. They are the result of evolving customer needs or a significant need for change. At the end of the 18th century for instance, bank holidays were introduced in many countries; 
factory workers and clerks had more time for leisure activities, such as going to the seaside or the countryside, but often did not have the means to purchase their own mode of transportation. At the same time, as towns grew in size and trade developed between cities and countries, new and more efficient ways of transporting goods and people to work or to their holiday destinations had to be invented: Steam ships, trams and trains. When the Benz Patent-Motorwagen car was invented in 1885, it was first considered a revolutionary innovation in technology, but it was not yet a disruptive innovation, because only the wealthy had the means to buy automobiles. It took years before the automobile industry disrupted the horse-drawn carriage business. Some lost their jobs, others learned a new trade (such as driver), new jobs were created (mechanics, etc.). Trains were the first disruptors as they became the transport of choice for poorer people: they were fast, relatively safe and affordable. To cater to this new wave of tourists, seaside resorts and services such as hotels, inns, ice cream vendors and restaurants started to appear. The wealthy purchased lands and built holidays homes, which in turn helped create and develop a real estate market. Christensen argued in The Innovator's Solution (2003) that it is rarely the technology per se that is intrinsically disruptive but rather the business model that the technology is enabling that creates the disruptive impact. In other words, the uses companies or people make of it and the further innovations that it enables them to undertake. It is also the use people make of it that often seems to set in motion the decline of a product or a service. The invention of the printing press by Johannes Gutenberg in the 15th century was a disruptive technology first before becoming a disruptive innovation. It gradually made the manual copying of manuscripts obsolete and new jobs started to appear e.g. movable-type printer, as this industry developed, improved and expanded. In 2016, mobile phones have often replaced landlines and emails are more commonly sent than letters. Public telephones have almost disappeared from the streets and the postal services or public libraries have had to rethink their services. Another important point worth mentioning is that certain particular elements of a technological change can be more or less disruptive and the level of disruption may differ and impact to a greater or lesser extent different/specific areas, within various timeframes, shorter or longer. William Ogburn's cultural lag's theory (1964) described in On Cultural and Social Change, suggested for instance that the effects of a technology would not be visible to social actors for some time after its introduction to a society, in other words, a period of incubation or maturation was needed, similar to a virus. Telephones and computers are such examples of technologies. A more recent example of a possible interesting gamechanger in the art industry is the use of big data in art galleries and museums to identify and understand audience behaviour (journey maps), design future exhibits and tailor-make messages to visitors' smartphones (Gamerman, 2014)."

MOOCs (Massive Open Online Courses), that have gained widespread attention in the recent years, have been referred to as the "new revolution" of the twenty-first century, "the single most important experiment in higher education" (Weissmann, 2012), "the magic bullet" (Chafkin, 2013), and "the change needed after 1000 years of higher education calcification" (Weissmann, 2012): [MOOCs revolutionise higher education and learning; MOOCs change the world; MOOCs democratise access to education; MOOCs expand the audience for education to people who are underserved or completely shut out of the current system; MOOCs bridge digital and social divides; MOOCs will unlock the gates to accessibility and affordability in education; MOOCs will replace universities] are all statements made on the internet and in the media about massive open online courses. (Bulfin et al, 2014) have attracted the curiosity of educators and spurred hope for change in academic circles as a result of their findings (Shirky, 2012). With their potential to "expand access to higher education to all," as Yuan and Powell (2013) put it, MOOCs have piqued widespread interest, sparked debate, and 
sparked heated discussion about their ability to simultaneously reach thousands students from every connected corner of the globe and from every socioeconomic background (Valenza, 2012), at a fraction of the cost, and with potentially high Returns on Investment (Yuan and Powell, 2013, p.8).

\section{Gamification in Higher Education}

In recent years, the use of gamification features in educational settings has grown, garnering the attention of researchers who are studying the topic. Gamifying learning systems has the potential to improve students' learning performance as a standalone informative activity (Bilgin, C. U., \& Gul, A., 2020; Alasmari, T., 2020; Krath, J., Schürmann, L., \& von Korflesch, H. F., 2021). Ultimately, the goal is to motivate students in novel ways, such as by reducing boredom in some tasks and promoting participation in learning activities that would increase learning outcomes (Legaki, N. Z., Xi, N., Hamari, J., Karpouzis, K., \& Assimakopoulos, V, 2020). However, despite the fact that gamification elements such as badges, points, and leader boards can be used in educational systems to motivate or engage students in order to increase participation and learning, the information systems literature does not clearly distinguish between experiential and instrumental outcomes of gamified educational environments. So while the literature continues to employ diverse notions interchangeably (Dichev and Dicheva 2017), additional research is required to progress this area."

\section{Gamification in Higher Education}

Many of the characteristics of the gamification literature in educational contexts are the same as those of the gamification literature more generally. The dual-outcome notion (experiential-instrumental) can be found in gamified learning systems aimed at boosting learning, for example. (Dichev and Dicheva 2017; Fitz-Walter et al. 2017; Landers 2014; Looyestyn et al. 2017). For the purposes of this discussion, experiential objectives are frequently linked to hedonic or affective outcomes, whereas instrumental goals are linked to observable educational outcomes like test scores and retention (Dichev and Dicheva 2017; Hamari et al. 2014). However, the same variation in result classification that can be observed in the gamification literature can also be found in studies that focus on educational results. Many scholar (Dichev and Dicheva, 2017) identified common categories of outcomes used in educational gamified systems (such as knowledge acquisition, perceptions, behavioural, engagement, motivational, and social) but did not provide any additional information on whether these outcomes are experiential or instrumental."

\section{SIMULATION}

Simulation-based learning is effective in encouraging the use of evaluative and critical thinking, which is an aspect of traditional education that has yet to be completely explored. Game-based learning is frequently employed in the field of education, and there is already a substantial body of study on the subject of gamification and usage in education (Yang et al, 2010; Liu et. al, 2011). With the development of digital or web-based games in recent years have gained popularity as a method of assisting students in their learning. The study is set out to explore the online education, this research topic piques the interest of the scientific and educational communities, which includes tutors, students, and game designers, among other people. Because of technological advancements, educators and policymakers are growing more interested in adopting practical advantages in technical tools into their pedagogy, such as video games, virtual reality, simulation and online Games (Gómez, 2014).

The use of simulators creates a set of circumstance in which learner can applied application of existing knowledge and practical abilities to real-life circumstances while also allowing teachers to achieve their own objectives (Andréu et al., 2011; Angelini, 2015; Garca-Carbonell et al., 2015). 
Participating in situation-based training allows the player to develop critical and creative skills such as communication, decision making, negotiation skills, teamwork, and leadership skills amongst other things (Flanagan et. al, 2004). Collaboration and information exchange are fostered as a result of the practical scenario, which can be completed as a team or individually (Robertson et al., 2009).

As a result of the proliferation of technologies, increased demands to interact with technology applications in a Information access, shared ideas, knowledge exchange, and content production have all improved as a result of this collaborative and participatory approach. (McLoughlin \& Lee, 2008). Student engagement in interactive, authentic, and self-directed knowledge acquisition is becoming increasingly common in higher education, thanks in part to the usage of digital simulations. It was found that game-based e-learning is a digital strategy that delivers, supports, and enhances teaching, learning, assessment, and evaluation through the use of video games. A distinction should be made between gamebased e-learning and game-based learning (GBL), which covers both computer and noncomputer games."

\section{Augmented Reality/virtual reality}

In higher education, augmented reality and virtual reality $(\mathrm{AR} / \mathrm{VR})$ are primarily employed for a variety of purposes. AR adds digital features to digital gadget cameras, such as Snapchat lenses, whereas VR creates an experience that isolates the physical world. HTC Vive, Google Cardboard, and Oculus Rift are some of the VR devices available (Flavin, 2017). In higher education, augmented reality is utilised to enrich students' environments by allowing them to engage with and see concepts, making them easier to study and comprehend. On the other hand, implementing AR/VR is challenging because there is no pedagogical guide and no best practises (Schmidthuber, Maresch \& Ginner, 2020).

VR and AR can improve participation and involvement in the teaching-learning process. Virtual tours allow students to participate in their studies altogether. So including them in the learning process is more efficient and productive. VR and AR applications use photos, sounds, text, and other data to create digital real-world ecosystems and visualizations. VR uses in education include engineering, medicine, and the military. The projected teaching and learning system will include $\mathrm{AI}, \mathrm{VR}$, and AR. The advances in these new sectors of technology will radically alter classroom instruction. However, technology is improving and helping many students. It is one of the most significant modern effects on the Indian education system, affecting higher education. VR is thus primed to grow in popularity and significance in the future. The country's teaching-learning community will benefit from improved tools for augmented prototyping.

VR and AR can enhance educational programs. Technology has dramatically altered millennials' brain circuitry and thinking style. Today's students are less interested in books. Their preferred learning method is to watch videos and visual demonstrations of what is taught in the classroom through those books. Technology has played a significant role in this shift in educational delivery.

In recent years, there has been minimal discussion about the use of Augmented Reality (AR) to promote educational inclusiveness. According to this comprehensive study, the current state of adopting augmented reality as an instructional technology that serves the needs of all students, including those with disabilities, has not yet been established. It is accomplished through an examination of aspects such as the benefits of augmented reality, its limitations, applications, problems, and scope in the educational field, the audience, and the positive and negative consequences of its use in learning situations involving students with varying educational requirements, among other things. Learning experiences that have been shown to influence learning processes in a variety of ways 
have been made possible by advancements in information and communication technologies (ICT). Lin et al. (2015) found that the use of a variety of online platforms has not only increased educational coverage by e-learning but has also made them more diverse. For example, ubiquitous learning (ulearning), augmented reality (AR), virtual reality (VR), mobile learning (m-learning), gaming, gamification, and learning analytics are some of the trends in education today (Nincarean et al., 2013). The use of mobile devices in education has also expanded as a result of recent technology breakthroughs, with the majority of mobile devices being used to assist children with impairments or a range of educational needs (Lin et al., 2016). "

Aspects of augmented reality (AR) in particular mix and superimpose real-world items with information and virtual objects (Azuma et al., 2011). Azuma et al. (2001) propose that augmented information can be applied to all senses at the same time, including hearing, smell, and touch. In light of these findings, AR appears to be a potential strategy for fostering educational inclusion processes (Sheehy et al., 2014), since it supports a variety of modalities of representation, action, and student participation in the learning process (Meyer et al., 2014). This claim is supported by a small body of scientific evidence. Researchers Hrishikesh and Nair (2016) discovered that augmented reality (AR) aids youngsters with learning impairments in comprehending things more quickly and efficiently. Furthermore, according to Mohd Yusof et al. (2014), augmented reality (AR) provides children with special needs with engaging and enjoyable teaching tools since it attracts their attention. Furthermore, evidence suggests that augmented reality (AR) improves students' educational experiences by increasing confidence, commitment, and interest (Fombona et al., 2017), providing opportunities for self-learning (Akçayir and Akçayir, 2017), enhancing collaborative learning (Phon et al., 2014), and increasing satisfaction and motivation (Fombona et al., 2017). (Liu and Chu, 2010; Di Serio et al., 2013; Bacca et al., )
"Literature reviews on the use of AR in education analyze its development, as well as relevant aspects of use, however, as indicated by Gavilanes et al. (2018) when summarizing literature reviews on the use of AR in education until 2017, it is necessary to also analyze the potential of AR to support students with diverse needs, including those with disabilities."

\section{WEB CASTING}

To ensure student-centric learning, the traditional education model, which is characterised by silobased learning and exam-based systems of evaluation, must be replaced with inventive means of delivering education. It is vital for educational institutions to align their approach to students' expectations and the ever-changing dynamics of the future of employment. Webcasting's usability in teaching and learning has increased as a result of fundamental changes in education technology and the growth of the internet. The fundamental benefit of webcasting is that it eliminates physical barriers, allowing students to attend classes from anywhere. In the online version, it has enhanced student and instructor involvement and interaction. Through webcasting, several online tools such as video, audio, online quizzes, text, images, and many more can be integrated into the teaching and learning module. Many studies have demonstrated that webcasting allows learners to quickly track and access their progress.

Video and audio content is increasingly being distributed via webcasting. Webcasts can be used in the classroom by many educators (Bell, 2003; Copley, 2007; Giannakos \& Vlamos, 2012). For note-taking and exam review, Scutter, Stupans, Sawyer and King (2010) and Deal (2010) recommend webcasting lectures in their entirety (2007). According to Van Zanten, Somogyi, and Curro, students frequently use webcasts for revision and review during exam preparation (2012). It is possible to use webcasts for a variety of purposes, according to Harris and Park (2008). These include information delivery, 
complementing class materials and guest lecture appearances. Indeed, we'd like to assert that webcasts make it straightforward for a prospective student to study any subject he or she so wishes.

The literature is reviewed to examine how students get benefited having lectures through webcasting medium that could be used students who attending class remotely (Evans, 2008). A number of studies have examined that the positive attributes of webcasting such as it helps to overcome the physical boundaries of classroom, it highly engaging by adding polls, sharing result in real time, and interactive by adding power point, online quiz or by sharing content. Session can also record and consume on demand. Webcasting also help academia in boarding learning and knowledge spectrum by inviting guest lecture, industrial personality and faculty from esteemed institute (Dale \& Pymm, 2009). Maag (2006). The number of studies that have investigate that webcasting utilize videos and questions to create an interactive learning experience. By assigning a quiz following the webcast. All answers are available on the presenter's website, and students can view their scores in real time. While digital learning and educational webcasts are not novel concepts, they have not been extensively adopted as the principal method of class facilitation. In education, webcasting enables universities and colleges to engage in ways they were before unable to. Given the unusual nature of the current era, webcast software can be a tremendous advantage to institutions.

The cognitive theory of multimedia learning could explain why webcasts do so well. A learner's system, according to the theory, has dual channels for visual and verbal processing, and a learner creates knowledge by integrating information from both channels (Mayer, 2001, p. 41). A number of studies (Giannakos, Chorianopoulos, Johns, Inkpen \& Du, 2011) have examined that student learn and communicate better from words and pictures than from words alone. Webcasting studies, for example, have looked at government documents in the public sector. (Library $\mathrm{Hi}$ Tech) and private sectors (Haygood, 2007). Several studies have explored the effects of webcasting in higher education (Giannakos \& Vlamos, 2010; Yunus et al, 2006) and by adopting latest tools and technologies in teaching and learning may motivated instructor and learner and optimum performance of teachers. Traditional way of teaching in the classroom is more emotional, more cognitive and social experience where instructor teach as inperson to learner and body language and eye contact with learner create curiosity and confidence in learners; direct questions makes the students more attentive and creates a learning ecosystem (Nordkvelle, Fritze \& Haugsbakk, 2009). In contrast, teaching through webcasting platform, make class more monotonous and one way communication."

Conventional approaches are based on the concept, that in webcasts are viewed on a computer screen as a filtered version of the teacher's reality, filtered through a range of technological processes and skills. As a consequence, a personal reaction to the webcast will not be the same as traditional instruction provided in the class. This led researchers to investigate more sophisticated techniques to conducted to students acceptability, emotionally and socially aspects of the use of webcasts, and continue adoption of online platform for instance, video, social media, YouTube, satellite repositories (Gkonela, 2011), and online webcast group (Khan Academy), and many other platforms.

\section{CONCLUSION}

The Fourth Industrial Revolution (Industrial 4.0) has altered the way we think about schooling. A change in teaching methods is vital, but a applying new teaching methodology in existing pedagogy is far more important than changing teaching methodology. Virtually every aspect of education, such as pedagogy development, instructor's competency and skills development, and the most important usability of technology into the teaching and learning process, will be affected by the continuous adoption of technology. As a result, 
existing and future pedagogy must focus on students' learning capabilities, life-long learning skills, and thinking critically and creatively. Higher education learning is becoming more real for more generation $\mathrm{Z}$ students from areas where communities do not prioritize education. Students who lack the resources to proceed with the higher education program have been able to join the online programs, which are equally competitive, but the cost is minimal. Disruptive technology has changed people's mindset that they have to attend full-time university programs for you to successfully acquire the necessary knowledge. With the use of technology, it is imperative to establish that the world is making progress regarding access to education, delivery of knowledge, and application of disruptive technology.

\section{REFERENCES}

Akçayir, M., and Akçayir, G. (2017). Advantages and challenges associated with AR for education: a systematic review of the literature. Educ. Res. Rev. 20, 1-11. doi: 10.1016/j.edurev.2016.11.002.

Andreu Andrés, M. A., \& García Casas, M. (2011). Perceptions of gaming as experiential learning by engineering students. International Journal of Engineering Education, 27(4), 795-804.

Aoun, J. E. (2018). Robot-proof: higher education in the age of artificial intelligence. Journal of Education for Teaching.

Aziz Hussin, A. (2018). Education 4.0 Made Simple: Ideas For Teaching. International Journal of Education and Literacy Studies.

Azuma, R., Behringer, R., Feiner, S., Julier, S., and Macintyre, B. (2001). Recent advances in AR. IEEE Comput. Graph. Appl. 2011, 1-27. doi: 10.4061/2011/908468

Azuma, R., Billinghurst, M., and Klinker, G. (2011). Special section on mobile AR. Comput. Graph. 35, vii-viii. doi: 10.1016/j.cag.2011.05.002

Bell, S. (2003). Cyber-guest lectures: using webcasts as a teaching tool. TechTrends, 47, 4, 10-14.doi:10.1007/BF02763506

Buckless, F. A., Krawczyk, K., \& Showalter, D. S.
(2014). Using virtual worlds to simulate realworld audit procedures. Issues in Accounting Education, 29(3), 389-417.

Bulfin, S., Pangrazio, L. and Selwyn, N. (2014) Making 'MOOCs': The construction of a new digital higher education within news media discourse. The International Review of Research in Open and Distributed Learning, 15(5).

Chafkin, M. (2013) Udacity's Sebastian Thrun, Godfather Of Free Online Education, Changes Course. Fast Company.

Chiang, Y. T., Lin, S. S. J., Cheng, C. Y., \& Liu, E. Z. F. (2011). Exploring online game players' flow experiences and positive affect. The Turkish Online Journal of Educational Technology, 10(1), 106-114.

Chorianopoulos, K., Leftheriotis, I. \& Gkonela, C. (2011). SocialSkip: pragmatic understanding within web video. In Proceedings of the 9th International Interactive Conference on Interactive Television (25-28). New York, NY: EuroITV'11. ACM.

Christensen, C.M. (1997) The Innovator's Dilemma: When New Technologies Cause Great Firms to Fail. Boston. MA: Harvard Business School Press.

Connolly, T., \& Stansfield, M. (2006). Using gamesbased eLearning technologies in overcoming difficulties in teaching information systems. Journal of Information Technology Education, $5(1), 459-476$.

Copley, J. (2007). Audio and video podcasts of lectures for campus-based students: production and evaluation of student use. Innovations in Education and Teaching International, 44, 4, 387-399.

Deal, A. (2007). A teaching with technology white paper: podcasting. Retrieved March 11, 2011, from Carnegie Mellon University Eberly Center of Teaching Excellence and Office of Technology for Education.

Dichev, C., and Dicheva, D. 2017. "Gamifying Education: What Is Known, What Is Believed and What Remains Uncertain: A Critical Review," International Journal of Educational 
Technology in Higher Education (14:1), pp. 1-36.

Dichev, C., and Dicheva, D. 2017. “Gamifying

Education: What Is Known, What Is Believed and What Remains Uncertain: A Critical Review," International Journal of Educational Technology in Higher Education (14:1), pp. 1-36.

Di Serio, Á., Ibáñez, M. B., and Kloos, C. D. (2013). Impact of an AR system on students' motivation for a visual art course. Comput. Educ. 68, 585-596. doi: 10.1016/j.compedu.2012.03.002.

Evans, C. (2008). The effectiveness of m-learning in the form of podcast revision lectures in higher education.Computers \& Education, 50, 2, 491-498.

Fitz-Walter, Z., Johnson, D., Wyeth, P., Tjondronegoro, D., and Scott-Parker, B. 2017. "Driven to Drive? Investigating the Effect of Gamification on Learner Driver Behavior, Perceived Motivation and User Experience," Computers in Human Behavior (71), pp. 586-595.

Fisk, P. (2017). Education 4.0 ... the future of learning will be dramatically different, in school and throughout life.

Flanagan, B., Nestel, D., \& Joseph, M. (2004). Making patient safety the focus: Crisis resource management in the undergraduate curriculum. Medical Education, 38(1), 56-66.

Fombona, J., Pascual-Sevillano, M.-A., and GonzálezVidegaray, M. (2017). M-learning and AR: a review of the scientific literature on the WoS Repository TT-M-learning y realidad aumentada: revisión de literatura científica en el repositorio WoS. Comunicar 25, 63-71. doi: 10.3916/C52-2017-06.

Gamerman, E. (2014) When the Art is watching you. The Wall Street Journal .

Gavilanes, W., Abásolo, M., and Cuji, B. (2018). Resumen de revisiones sobre Realidad Aumentada en Educación. Espacios 39:14.

Giannakos, M. N. \& Vlamos, P. (2010). Comparing a well designed webcast with traditional learning. In Proceedings of the 2010ACMConference on InformationTechnology Education. (65-68). NewYork, NY:SIGITE '10. ACM. doi:http: //doi.acm.org/10.1145/1867651.1867669
Giannakos, M. N., Chorianopoulos, K., Johns, P., Inkpen, K. \& Du, H. (2011). Children's interactions in an asynchronous video mediated communication environment. In Proceedings of the 13th IFIP TC 13 INTERNATIONAL Conference on Human-Computer INTERACTION-Volume Part I, (199-206). Berlin, Heidelberg: Springer-Verlag.

Giannakos, M. N., Chorianopoulos, K., Johns, P., Dale, C. \& Pymm, J. (2009). Podagogy: the iPod as a learning technology. Active Learning in Higher Education, 10, 1, 84-96.

Giannakos, M. N. \& Vlamos, P. (2012). Educational webcasts' acceptance: empirical examination and the role of experience. British Journal of Educational Technology. doi:10.1111/j.14678535.2011.01279.x

Hamari, J., Koivisto, J., and Sarsa, H. 2014b. “Does Gamification Work? - a Literature Review of Empirical Studies on Gamification," System Sciences (HICSS), 2014 47th Hawaii International Conference on: IEEE, pp. 3025-3034.

Hanus, M. D., and Fox, J. 2015. “Assessing the Effects of Gamification in the Classroom: A Longitudinal Study on Intrinsic Motivation, Social Comparison, Satisfaction, Effort, and Academic Performance," Computers \& Education (80), pp. 152-161.

Harris, H. \& Park, S. (2008). Educational usages of podcasting. British Journal of Educational Technology, 39, 548-551. doi:10.1111/j.14678535.2007.00788.x

Haygood, D. M. (2007). A status report on podcast advertising. Journal of Advertising Research, 47, 4, 518-523.

Hrishikesh, N., and Nair, J. J. (2016). “Interactive learning system for the hearing impaired and the vocally challenged," in 2016 International Conference on Advances in Computing, Communications and Informatics, ICACCI 2016 (Jaipur).

Kutz, B. L., Fenwick, J. B. \& Ellsworth, C. C. (2007). Using podcasts and tablet PCs in computer science. In Proceedings of the 45th Annual ACM Southeast Regional Conference. Winston-Salem, 
NC.

Landers, R. N. 2014. “Developing a Theory of Gamified Learning: Linking Serious Games and Gamification of Learning," Simulation \& Gaming (45:6), pp. 752-768.

Lin, C., Chai, H., Wang, J., Chen, C., Liu, Y., Chen, C., et al. (2016a). Augmented reality in educational activities for children with disabilities. Displays 42, 51-54. doi: 10.1016/j.displa.2015.02.004

Lin, C., Chen, C., Liu, Y.-H., Hua-Chen, C., Lin, C.W., Huang, Y.-M., et al. (2015). "Integrating motion-capture AR technology as an interactive program for children," in LNCS, Vol. 9177, eds. M. Antona and C. Stephanidis (Los Angeles, CA: Springer), 149-156.

Looyestyn, J., Kernot, J., Boshoff, K., Ryan, J., Edney, S., and Maher, C. 2017. "Does Gamification Increase Engagement with Online Programs? A Systematic Review," PLoS ONE (12:3), pp. 1-19.

Maag, M. (2006). IPod, uPod? An emerging mobile learning tool in nursing education and students' satisfaction. In Proceedings of the 23rd Annual Conference of the Australian Society for Computers in Learning in Tertiary Education.

Mayer, R. E. (2001). Multimedia learning. New York: Cambridge University Press.

McLoughlin, C., \& Lee, M. J. W. (2008). The three P's of pedagogy for the networked society: Personalization, participation, and productivity. International Journal of Teaching and Learning in Higher Education, 20(1), 10-27.

Meyer, A., Rose, D., and Gordon, D. (2014). Universal Design forLearning: Theory and Practice. Vol. 91.

Mohd Yusof, A., Sarojini Daniel, E. G., Low, W. Y., and Ab Aziz, K. (2014). Teachers perception of mobile edutainment for special needs learners: the Malaysian case. Int. J. Incl. Educ. 18, 1237-1246. doi: 10.1080/13603116.2014.885595.

Nincarean, D., Alia, M. B., Halim, N. D. A., and Rahman, M. H. A. (2013). Mobile AR: the potential for education. Proc. Soc. Behav. Sci. 103, 657-664. doi: 10.1016/j.sbspro.2013.10.385.

Nordkvelle, Y. T., Fritze, Y. \& Haugsbakk, G. (2009).
The visual in teaching-from Bologna to YouTubiversity. Medien-Wissen-Bildung. University of Innsbruck.

Ortiz-Rojas, M., Chiluiza, K., and Valcke, M. 2017.

"Gamification and Learning Performance: A Systematic Review of the Literature," European Conference on Games Based Learning: Academic Conferences International Limited, pp. 515-522.

Phon, D. N., Ali, M. B., and Halim, N. D. (2014). "Collaborative AR in education: a review", in 2014 International Conference on Teaching and Learning in Computing and Engineering (Kuching: IEEE), 78-83. doi: 10.1109/LaTiCE.2014.23.

Robertson, B., Schumacher, L., Gosman, G., Kanfer, R., Kelley, M., \& DeVita, M. (2009). Simulationbased crisis team training for multidisciplinary obstetric providers. Simululation in Healthcare, 4(2), 77-83. doi:10.1097/SIH.0b013e3181917cd.

Scutter, S., Stupans, I., Sawyer, T. \& King, S. (2010). How do students use podcasts to support learning? Australasian Journal of Educational Technology, 26, 2, 180-191.

Sheehy, K., Ferguson, R., and Clough, G. (2014). "Augmenting learners: educating the transhuman," in Augmented Education, eds K. Sheeh, R. Ferguson and G. Clough (New York, NY: Palgrave Macmillan), 137-158.

Shirky, C. (2013) Your Massively Open Offline College Is Broken. The Awl.

Sudlow, B. (2018). Review of Joseph E. Aoun (2017). Robot Proof: Higher Education in the Age of Artificial Intelligence. Postdigital Science and Education.

Thompson, C. (2011). How Khan Academy is changing the rules of education. Wired Magazine.

Valenza, J. (2012) MOOCs for kids too. School Library Journal. [blog].

Van Zanten, R., Somogyi, S. \& Curro, G. (2012). Purpose and preference in educational podcasting. British Journal of Educational Technology, 43, 1, 130-138. doi:10.1111/j.14678535.2010.01153.x 
Virvou, M. \& Katsionis, G. (2008). On the usability and likeability of virtual reality games for education: the case of VR-ENGAGE. Computers and Education, 50, 154-178.

Weissmann, J. (2012) The Single Most Important Experiment in Higher Education. The Atlantic.

Yang, J. C., Chen, C. H., \& Jeng, M. C. (2010). Integrating video-capture virtual reality technology into a physically interactive learning environment for English learning. Computers \& Education, 55(3), 1346-1356.

Yuan, L. and Powell, S. (2013) MOOCs and disruptive innovation: Implications for higher education. Open Education Europa.

Yunus, A. S., Kasa, Z., Asmuni, A., Samah, B. A., Napis, S., Yusoff, M. Z. M. et al (2006). Use of webcasting technology in teaching higher education. International Education Journal, 7, 7, 916-923. 